\title{
Effect of Globalization on Higher Education: WTO/GATS and Cross-Border Provision of Higher Education in Nigeria
}

\author{
Adegboyega Oyebajo Okunuga ${ }^{1}$, Athanasius I. Opara ${ }^{2}$, \\ Joy Chimebere Iyiegbuniwe ${ }^{3}$ \\ ${ }^{l}$ Distance Learning Institute University of Lagos Lagos, Nigeria \\ ${ }^{2}$ Distance Learning Institute University of Lagos, Nigeria \\ ${ }^{3}$ Distance Learning Institute University of Lagos, Lagos, Nigeria
}

\begin{abstract}
The world is fast becoming a global village where national boundaries which had hitherto limited human interactions are fast disappearing. There is now integration among the countries and trade is moving from transactions in goods and commodities to include the commercialization of education, especially postsecondary school or higher education.
\end{abstract}

Key Words: Globalization, Cross-border, WTO, GATS, Open and Distance Education

\section{Introduction}

The old world order is fast changing, proving the old adage that "nothing is more permanent than change", as old things are passing away very rapidly, giving room for new ones. This phenomenon is brought about by a form of global integration, known as globalization, which is accelerated by the rapid (ICT) development in the Information and Communications Technologies (ICT).

In the last two decades, especially the last decade of the $20^{\text {th }}$ century, old political and economic alliances are breaking down giving place to new ones (Ojo, 2004). For example, the Berlin Wall, which had since the end of World War II, separated the two previous German zones has been demolished (in 1991) giving way to a unified Germany. The USSR which had been the arrow-head of the former Eastern Block favouring communism, had been decimated to Russia, and numerous previously unheard-of nations such as Kazakstan, Uzbekistan, Turkmenistan, Kyrgystan, Tajikistan, etc. Alongside this, the former Eastern political block has become a shadow of its old self. Rather than segregating and barricading itself behind the old and small political divisions, the world has now opted for larger, wider and bigger entities. For example, Europe is now unifying into the European Union (EU), with a common currency and other cooperative bondings. The in-thing the world over is integration between formerly separate entities (Ojo, 2004).

\section{African Integration}

The European Union (EU) has made tremendous achievements through the existence of trans-border development agencies such as European Outline Convention, Euragio, Regiobasilensi, the formation of common immigration policy for the "Shengen States" and the liberation of trade among member states, sealed with a unifying currency, the Euro $(\notin)$. The EU has also developed transnational educational institutions and programmes such as:

(a) ERASMUS (European Community Action Schemes for the Mobility of University Students). This involves a student and faculty exchange programme with the participation of some 1,500 institutions and over 100,000 students annually.

(b) COMETT (Community programme for Educating and Training in Technology Field). This was created to support cooperation between universities and universities through training partnership.

(c) TEMPUS (Trans-European Mobility Schemes for University Studies), was formed in 1990 to promote cooperation between universities in Central and Eastern Europe.

(d) The International Scheldt Faculty (ISF), founded in 1990. The ISF offers what is called "EuroMasters" degrees through courses in networked universities and polytechnics in Holland, Germany and South-Eastern UK (Zeleza, 2003).

(e) The Cross Border University (CBU) is jointly funded by Finland and Russia

Africa has also awakened, though belatedly, to this aspect of regional cooperation through the formation of regional bodies. A few countries in some of the regional economic groupings are showing interest in transnational, inter-regional and cross-border cooperation in the area of higher education. However, this development is still in its infancy (Ojo, 2004). 
Within the African continent, there are five known sub-regional groupings:

(i) $\quad$ AMU (Arab Maghrebian Union) with five (5) countries.

(ii) COMESA (Common Market of Eastern and Southern Africa) comprises of twenty (20) countries.

(iii) ECCAS (Economic Community of Central African States) has eleven member-countries.

(iv) SADC (Southern African Development Community) is made up of fourteen countries.

(v) ECOWAS (the Economic Community of West African States) has fifteen countries in its fold.

Although these African countries have engaged in trade and economic relationships within their regional groupings, education, which ought to be seen as the engine-room of economic buoyancy and development, has not really been given the priority status it deserves (Ojo, 2004). African nations must redress this anomaly in view of the pivotal role that higher education plays in development.

Most countries have now realized the importance of post-secondary (higher) education sector in contributing to the country's human resources, and investment in the sector has played a decisive role in economic growth (Fagbamiye, 2004). The post-secondary school sector has also been seen as being responsible for the establishment and expansion of research infrastructure and serves as a forum for generating, discussing and disseminating new ideas (EI, 2002).

\section{Globalization and the Development of ICT}

The Information and Communication Technology has grown very fast in the last few decades. ICT has reduced the whole world into a global village, bringing peoples, races and nations closer that the artificial boundaries separating them have been effaced. Within a village one hollers at one end and can be heard at the other end. With ICT, transmission of information does not encounter any national or regional boundaries; a "holler" on the ICT in one country could be "heard" in any part of the world within a few seconds via the internet and e-mail.

The ICT has made learning a life-long endeavour, and electronic learning (e-learning) has the advantage of bringing into the bedrooms of individuals skill-based education and training programmes at reduced costs, and at one's convenience.

Networking has helped in reshaping world outlook and has allowed knowledge to become a monumental, pan-human property (Ojo, 2004). Networking within the academics is enhancing a lot of cooperation, harmonization of views, exchanges, linkages, cross-fertilization of knowledge and realignment of approaches and methodologies between scholars belonging to institutions and research centres within the same country or outside their countries. Integration also occurs between identical or different linguistic entities and even between divergent races with differing cultures, national histories, economic systems, and administrative organizations (Ojo, 2004).

The in-thing now in the world is integration between formerly separate entities. Where the 1960's saw active competition in the space race between the world's super powers, now there are joint explorations into the outer space.

Information and Communication Technologies, especially the internet, virtual library, e-learning and Distance Education (DE) have made the transmission of information/knowledge very fast, crossing borders faster than the speed of light. ICT has enhanced anew world cooperation and harmonizing strategies of integration, interdependence, synergy, networking and globalization.

The effect of ICT-induced globalization is more realistic in the Western world and South-East Asia than in Africa. While the developed countries in these regions are enjoying the full benefits of the ICT, Africa is still mostly in slumber, or at best, sleep-walking into the ICT world. The use of ICT in Africa is very low. Africa's use of the ICT is very rudimentary. Although many African universities have their own web sites, the internet and e-mail are rarely used for teaching, learning, curriculum development and research except in the better endowed universities in South Africa and Egypt (Zelezan, 2003).

The main reasons for Africa's ICT backwardness are political (state-centric, domestic and policyoriented), economic and technological. However, in the developed countries of the West and South-East Asia where the political system is much stable and better mature than in Africa, and also where the economy is stable, better developed and more advanced new technologies are receiving substantial servicing, there is full enjoyment of trans-border cooperation strategies.

Hence those developed countries, found mostly in Western Europe, North America and South East Asia are opening their doors and borders to one another and are becoming better developed and more advanced because information needed for research are swift in coming and better research products are churned out daily. These cooperating, synergistic and interacting countries are reaping the heavy rewards of transcontinental, transnational and inter-regional cooperation and the pooling of policy-resources, talents and potentials. Africa is still in slumber and is yet to tap the benefits of the enormous resources and advantages that are laced into transnational, inter-regional and trans-regional cooperation. 


\section{Transnational Cooperation in the Area of Higher Education}

The advanced countries have cooperated in the areas of politics, economics, industry, social and technological spheres and education, all to the benefit and greater advantage of their citizens whose lives have been positively and advantageously touched. For exampled, a common currency, the Euro, is now the tenable currency in all member states of the European Union (EU), except Britain and Switzerland.

Another beneficial positive move is the abolition of strident immigration and custom rules which has made movements of citizens easy within European countries. There are also defence pacts signed between these interacting countries which bring better security to their citizens and this enhances developments when peace reigns.

This trans-national cooperation is very much also active in the area of higher education. In the EU, the "Europe without frontiers", initiated by France, Germany, Italy and Great Britain, and actively supported by fifteen (15) other participating countries has enhanced the internationalization of higher education in Europe. This has brought about compatibility in curriculum offerings in the countries, which has in turn bought about the harmonization of courses and degrees among these countries. This harmonized curriculum has made it possible for students to "hop" easily from one country to another, within the EU, and continue with their education without any loss of credit or any negative effect on the duration of their degree courses; this can happen regardless of differences in the mediums of instruction and national cultures between the countries the students transverse.

\section{Growth of Higher Education In Africa}

Education is seen as the cornerstone of national development. It plays a vital role in economic and technological development while removing illiteracy and poverty. Education helps in the development of a culturally and socially tolerant people who are able to exercise ethnical and moral considerations in national and local affairs, imbibed with community spirit (Jegede, 2000).

It is generally believed that the post-secondary education sector contributes substantially to the development of a country's human resources, and investment in the sector has played a decisive role in economic growth (Fagbamiye, 2004). The post-secondary school sector has also been responsible for establishing the expanding research infrastructure and has served as a forum for generating, discussing and disseminating new ideas (EI, 2002). It is also believed that the sector has also frequently helped to forge national identity by facilitating training and further training of public service employees through seminars, symposia, workshops, etc (Fagbamiye, 2004).

The Second World War (WW II) opened the eyes of many Africans, who were drafted into the war by their colonial masters, to the importance of education and heightened the clamour for independence. The thirst for knowledge through education grew very fiercely among the Africans, many of who travelled beyond their shores in search of the Golden Fleece.

After the gaining of independence by many African countries, a growing passion fuelled the aspirations of the people to seek education which was relevant to the demands of the new African nations. This was because the colonial masters gave Africans the education that limited them to being clerks, domestics, cooks and drivers. Courses in the sciences were missing from the curriculum and what prevailed were the classics such as Latin which was essentially a dead language and of minimal use outside the study of law.

Many Nigerians in the 1950's and 1960's studied at home in Nigeria through tutorial institutions such as the Rapid Results College, Exams Success, etc to prepare themselves as external candidates for the General Certificate of Education(GCE) Advance Level (A/L) and the Intermediate Bachelors of Arts (Inter B.A) before leaving the shores of Nigeria in search of the golden fleece in Europe, mainly Great Britain, United States of America (USA) and Canada. Many Nigerians also sailed the boat, MV Auriel, to study the humanities at the Fourah Bay University in Free-Town, Sierra Leone.

Immediately upon gaining independence, Nigeria instituted the Ashby Commission to chart the way for the establishment of higher institutions of learning in the country. Prior to this, in 1948, the premier university in the country the University College, Ibadan (UCI), later University of Ibadan (UI), had been established as an extension of the University of London. Indeed the first university colleges that were established in Africa, namely, Ibadan, Makarere, Khartoun, Dakar, etc, were branch campuses of universities in Western nations. Apart from being tans-national they also served as regional institutions in that they attracted students from different territories under the colonial masters. However, the rapid proliferation of national and sub-national universities in the 1970's changed the international/inter-regional character of the higher institutions in Africa.

Besides the drastic reduction in the number of foreign students, almost all the expatriate lecturers in these universities were replaced by indigenous ones in the process of indigenization (Akinyele, 2004). 


\section{Internationalization/Commodification of Higher Education}

Information and Communication Technology (ICT) is a vastly growing area the potentials of which has not been totally realized. The rapid development in ICT has drastically altered the way in which knowledge is transmitted. There are changing tides in the way education exists today because of ICT. Contemporary changes are occurring in the methods of delivery of instructions and this is significantly affecting and is being affected with regards to the transmission, distribution, accessing and processing of information and knowledge (Jegede, 2000).

The ICT has generated an exponentially increasing growth in knowledge which the world is finding difficult to keep pace with. Marshall (1996) noted that the half-life ( $\left.\mathrm{T}^{1} / 2\right)$ of any knowledge is limited to five (5) years. This means that in five years' time the knowledge we hold sacrosanct now would have become obsolete, necessitating us to have to go back to school to learn new knowledge. Knowledge, which had been restricted to a cluster of people has now become so vast and is majorly accessible to anyone and everyone though a variety of ways, especially through the information and communication technology system (Jegede, 2000).

\section{WTO/GATS and Higher Education}

A new prospect of internationalization of higher education under globalization has been opened under the World Trade Organization/General Agreement on Trade and Services (WTO/GATS). Under the WTO, countries have traded in commodities such as sugar, crude oil, cocoa, rubber, etc. Knowledge which is fastly spinning in magnitude has now been recognized as a marketable commodity. As knowledge is the bedrock of education, education itself has been adjudged a commodity that can be traded in.

Because of its potential as a lucrative money spinner, the World Trade Organisation (WTO) has turned its attention to supply of education across international borders, and since 1994, the General Agreement on Trade in Services (GATS), under WTO, has included education, especially higher education, on the list of services to be privatized/commodified. The WTO/GATS negotiations among member states would enhance the flow of students and educational resources, and colleges and campuses can be established in foreign countries.

\section{Definition of Terms}

(i) Higher Education: refers to knowledge, training, learning and teaching that are dispensed or received in a tertiary institution (such as universities, Colleges of Technology (monotechnics and polytechnics), Colleges of Education, etc) otherwise known as post-secondary institutions.

Cross-Border Education: This is education provided by individuals, agents, institutions and organizations based outside the borders of a country; the providers are involved in the provision, supply and management of courses, degrees, diplomas and other accompanying learning, evaluation, administration or academic related activities made available to interested persons in the host country, who are expected to pay for such programmes or course of study registered for. The place where the programme or course of study is handled can either be in the host country or in the country of origin of the cross-border provider.

(iii) Cross-Border Education Providers: Anyone organization or institution that provides education in a country other than the country of origin of source.

(iv) GATS: The General Agreement on Trade in Services (GATS) is one of several agreements adopted in 1994 as part of the newly established by the World Trade Organization. Nations have traded amongst and betwixt each other under international agreements. Under such WTO agreements nations had traded in commodities such as cocoa, timber, cotton, crude oil, etc, but not in services. GATS which was negotiated in Uruguay, and was midwifed by the WTO, being made up of 146 countries, is the first set of multilateral agreements that created international trade in services (Akinyele, 2004).

GATS was re-launched in 2000 with the goals of further liberalization of trade in services (EI, 2002). The coverage of GATS is very wide and only government procurement is explicitly excluded from GATS (Fagbamiye, 2004).

\section{GATS and Higher Education}

Cross-border education is not altogether a foreign concept or an entirely new one. In a simple way, cross-border can be described as a form of long distance education that involves crossing the border (Akinyele, 2004). It refers to the movement of education - whether it be people, programmes, programme providers or projects - across a jurisdictional or national boundary (Knight, 2003a, b).

Educators use the term "cross-border education" to capture a wide range of educational activities that are a part of international academic linkages and agreements, international developments/aids projects and 
international trade initiatives (Knight, 2003). Yet, trade in education is but a subset of cross-border education (Akinyele, 2004).

GATS has defined four modes of supply as defining the trade in services with regards to education (Akinyele, 2004; and Fagbamiye, 2004).

\section{Mode 1: Programme Mobility/Cross-border supply}

This involves the movement of the services, and not the consumer across national boundary. This covers such educational services transmitted through international mail, phone, fax, teleconference and the Internet. Distance education offered through the use of telephone, Internet and e-learning are included in this category, e.g. the University of South Africa (UNISA) and Indirah Gandhi Open University (IGNOU) offer degree courses in Nigeria through the internet.

\section{Mode 2: Student Mobility/Consumption Abroad}

This is currently the most popular model and involves the consumer (student) moving to the supplier's country, i.e. the student takes all or a part of his country in another (foreign) country. Studying abroad is considered an export of educational services, and advocates of privatization are clamouring for the removal of curbs (such as visa and non-recognition of certificates/diplomas) on the movements of students (Fagbamiye, 2004).

\section{Mode 3: Institutional Mobility/Commercial Presence}

This involves the commercial presence of the service provider in the country of consumption. This could exist as a branch or international campus, franchising or trans-international institutions, e.g. Cambridge University has a branch at Abule-Oja, Lagos for GCE A/Level courses (Fagbamiye, 2004) and Babcock University, Ilishan-Remo, Ogun State has a worldwide network through which a student can transfer within any of its 144 branches worldwide.

\section{Mode 4: Expert Mobility/Presence of Natural persons}

This involves the physical temporary movement of experts to other countries (the consumer country) to provide the service required. This could be in the form of lecturers going on sabbatical leave or teacherexchange programmes, the technical Aids Corps (e.g. the former American peace Corps programme of the 1960's or Nigeria's African Technical Aids programme), seminars, key note address, etc.

\section{Factors That Favour Gats/Cross-Border Education}

\section{Insufficient Number of Higher Institutions}

The insufficiency the existing universities for the teeming populace in Africa is a sure lee way for the thirst for cross-border education in Africa. Admittedly, the number of universities in different African countries has increased considerably since the 1960's, but so has the population and the hunger for knowledge and education at the tertiary level. For instance, Nigeria stated (in 1948) with only one university college (originally affiliated to the University of London), but now has 54 universities, 64 colleges of education and several polytechnics. Similarly, the East African countries of Kenya, Uganda and Tanzania initially jointly shared the Makarere College, and later the East African University that split into three in 1970, now have 14, 15 and 9 universities respectively, in addition to polytechnics (Jegede, 2000).

Nigeria is grossly under-provided with universities when compared in relative population size to other countries. Nigeria with a human population of about 120 million has 54 universities. France with 59 million people, half the population of Nigeria, has 81 universities. America, with about 266 million people, which is double the population of Nigeria has about 3000 universities (Ojo, 2004). The inadequacy in the number of universities in Nigeria for her vast population is thus very glaring.

\section{Unreasonably Low Number of Academics}

African countries most especially Nigeria, have been experiencing the phenomenon known as "brain drain". Professionals in various fields have left their countries to seek employment in foreign countries which they presume to be greener pastures. This brain drain has also affected the academics due to the poor remunerations given to lecturers. Also as a result of poor pay many young intellectuals have refused coming into the universities to teach. This has made the student: lecturer ratio very high such that lecture theatres are full to capacity and students spill out into the corridors.

\section{Unstable Socio-economic and Political Atmosphere}


Because of economic hardship demands of the academics for better working conditions are turned down by the various governments even after successful negotiations. This results in incessant strikes by both academic and non-academic staff of universities. The resultant effect is the frequent closure of universities and other higher institutions of learning. This amounts to inadequate teaching periods being used for academic tutoring and half-backed graduates who are usually rejected for postgraduate studies overseas. Nigerian employers also find it difficult to employ most of these graduates who know next to nothing about the course they claim to have graduated in from the universities.

The shortened academic periods of learning result in inadequate exposure of students to learning and, especially where practicals are involved. Incessant labour disputes which bring about strikes make the duration of any course unpredictable. Some normal four year programmes can extend to six years or more due to frequent closures.

\section{Underfunding}

In spite of the established fact of the importance of post-secondary education, it has been established that in many African countries, Nigeria included, expenditure has been increasing rather slowly and in some cases it has fallen, while enrolment has been increasing at a fast rate (OECD, 2000). UNESCO (2000) figures showed that there were over 90 million students in higher education worldwide. It also revealed that ordinary public expenditure was over US\$270 million (two hundred and seventy million US dollars). Students in developed countries who accounted for only $37 \%$ of the worldwide student population had $83 \%$ of the total expenditure spent on them. On the other hand students from developing countries who made up $63 \%$ of the worldwide student population had only $17 \%$ of the public expenditure spent on them.

This shows a lower amount of public funding for higher education in developing countries. However, in all countries, post-secondary education is primarily funded by the state (Fagbamiye, 2004).

Thus, the main cause of the malaise befalling rewarding learning and teaching in higher institutions in Nigeria is underfunding by the Federal and state governments who own most of them. This results in stressful and inadequacy in the payment of salaries, other remunerations and stipends to university staff which leads to industrial haggling that end up in strikes.

Underfunding also affects the provision of appropriate, adequate and up-dated/modern facilities, infrastructural spaces (classrooms and laboratories) and equipment for teaching, learning, research and domiciliation of students and staff. Another resultant effect of underfunding dilemma is that most of our universities libraries and those of individual academics are stored with out-dated books and journals making the dissemination, generation and up-dating of knowledge through research very difficult, unrewarding and unattractive (Ojo, 2004).

In developed countries where here are well-equipped research laboratories and libraries, academics teach from their own research findings and experiences. But in developing countries like Nigeria, academics make little or no fresh research of their own and can only regurgitate old research findings from their out-dated books and journals. There is thus staleness in the knowledge being transmitted in our higher institutions (Ojo, 2004).

Even, lack of funding to actualize the positive results of the few researches done make research unattractive to African academics. Thus, underfunding amongst other socio-economic problems strangulate free-thinking of academics and make learning experiences very inadequate, deficient, most often stressful, unrewarding and unproductive for most Nigerian students. The conducive atmosphere that is indispensable for a rewarding, fulfilling teaching and learning experience is acutely lacking, such that the products of higher institutions in Nigeria are regarded as "half-baked" or "unleavened" by employers of labour. This is why some students will prefer cross-border education to Nigeria's trifling form of education.

\section{Inadequacy of Admission Spaces}

Enrolment in higher education has been increasing at a fast pace so much that in developing countries like Nigeria, a very abysmally low percentage of qualified applicants secure admission yearly; the greater majority is left to seek alternate ways to get higher education at all costs. Hence, a lot of these disadvantaged people are forced to look towards cross-border learning paying anything to travel out of the country. For example, a recent release by the Joint Admissions and Matriculation Board (JAMB) showed that out of about 1.5 million Nigerians who seek admission to the nation's universities yearly, only about 160,000 of them get admitted (Akinyele, 2004). This is about the limit at which the present higher institutions in Nigeria can admit, keeping in mind the insufficiency of structural materials and teaching staff.

Other problems include deficiency in the admission process which has been subjected to racketeering ad manipulations by unscrupulous agents resulting in the admission of unqualified and unteachable students. This fact came out glaringly with the recent post-JME interactive sessions undertaken by most Nigerian universities; here it was revealed that candidates who scored glowingly high in the Joint Matriculation 
Examination (JME) were unable to do well in the post-JME tests, thus revealing the fact that their high scores at the JME were not products of their own efforts.

\section{Insecurity of Lives and Properties}

Africa is a pot shed of political instability which ultimately leads to intercine wars. Elections are usually not free nor fair and those who have thus secured the seat of power feel no obligation to the electorates. Thus they enrich themselves to the detriment of the citizens. Corruption and nepotism share the field of play and crimes escalate. There is hardly any peaceful transition through the ballot boxes. The only way those not holding the reins of government can get in is through a putsch. This usually has ethnic coloration and eventually leads to civil wars which disrupt meaningful academic life. Amidst insecurity of life and properties, most youngsters prefer to escape abroad in search of the Golden Fleece but chose not to return to their country of origin even after achieving their goals. This "brain drain" depletes the intellectual capacity of African nations and adds to their backwardness.

\section{Other Reasons}

Two other factors make cross-border higher education attractive to Nigerians. Firstly is the pervading craze for paper qualifications, especially at the university level. Secondly, is the "tokunbo mentality" which makes foreign products more appealing and better appreciated and most zealously sought after than those locally available (Ojo, 2004). For these reasons, Nigerians are ready to sell all and travel out, by any means possible, in search of the proverbial "golden fleece". And because of this most foreigners over-exploit, to their own monetary advantage, this craze and gullibility of Nigerians for foreign products, including higher education.

\section{Targeted Nigerian Recipients of Cross-border Higher Education}

With the above stated reasons for the attractiveness of cross-border higher education various categories exist among those who are the targets of cross-border providers of higher education in Nigeria.

1. those with "tokunbo" spirit who thirst for things provided by foreigners, especially those whose skins are not as dark as those of Nigerians. To this category of people anything from abroad is much better than "made in Nigeria" no matter the price disparity, usually in favour of the foreign goods.

2. those not admitted through JAMB into Nigerian universities for reasons ranging from reduced number of admission quota each year, limited available admission space, inadequacies of relevant facilities and resources.

3. Those who are deficient in the admission requirements but chose the more liberal systems of education of some foreign countries.

4. Those who are dissatisfied with the type of university education in Nigeria.

5. Those who are attracted to globalization, as it relates to the acquisition of knowledge seen as a pan-human patrimony.

6. Those who will feel more fulfilled and better provided with employable professional skills in courses other than those available within the country.

7. Those interested in specialized courses particularly new ones, most especially those in ICT, Sciences, Engineering and Management Sciences that are not available at all in Nigeria, or are not being competently, satisfactorily or professionally handled in Nigeria.

8. Those who are affluent enough and can afford the cost of tuition to pursue the courses provided by crossborder providers and are able to satisfy all the admission requirements (Ojo, 2004).

\section{The Past}

\section{Cross-Border Higher Education In Nigeria - Past And Present}

Cross-border education at the higher institutional level is not a new thing in Nigeria. The first set of Nigerians who benefited from higher education across the Nigerian borders is that of Nigerians who went to universities in West Africa (particularly Sierra Leon's Fourah Bay College), Great Britain and North America (USA and Canada most especially) in the early years of the last century. Some of these Nigerians did part of their studies through correspondence tutoring and completed them in the foreign countries.

To woo citizens from emerging and newly freed African nations the defunct Soviet Union (USSR) and its communist allies offered numerous academic scholarships which were taken up by many Nigerians. Similarly, the Commonwealth (a conglomeration of freed British colonists), Ford Foundation, Rockyfeller Foundation, British Council and other such bodies from the Western axis also offered scholarships. In the 1960's Cuba, the only communist country in the Western hemisphere offered scholarships and technical aids to many African countries. 
The courses for which the earliest recipients of cross-border higher education gunned for were the Humanities particularly the Classics, English and History, Divinity (or Religious Studies). Those who went to Great Britain pursued courses mostly in Law and Economics. Political Science and Education were more favoured by those who went to the United States of America (USA).

Science subjects were not too popular in the pre-independence days and were barely taught in the few secondary schools that existed. The few Nigerians who studied science in the secondary school were attracted to Great Britain and the USA.

The first category of recipients of higher education provided from across our borders got information about institutions in those foreign countries through their friends who had crossed over. Others obtained information via the acknowledge reputation of the institutions on the advice or motivation of their alumni, or through their sponsors (Ojo, 2004).

\section{The Present}

In recent times, particularly with new advances in Science and Technology, Nigerians now opt for courses in such areas as Information and Communication Technology, Health, Town Planning, petroleum and other Engineering courses (inclusive of Aeronautic Engineering). Other courses are in Business Administration, Stock Exchange, Accounting and Finance, and Actuarial Sciences which are patronized to service the growing business and industrial concerns in the country. It must be noted that most Nigerians attracted to such courses go in at the postgraduate levels.

The second category of Nigerians is won over as a result of copious advertisements through newspapers, the MSN Messenger, the Internet and through agents of cross-border providers that have their offices in Nigeria. At times, some of these institutions send their senior staff over to Nigeria to give seminars and interview would-be students on specific dates at different major cities in Nigeria.

Adverts by most British universities claim that the British Council in Nigeria is fully aware of their interests and proposals. They hold Consultations and Education Fairs and Expositions for prospective candidates through their Nigerian offices. Admission fees are charged for such organised fairs.

Some British Universities employ the services of Marketing Companies based in Nigeria to recruit students for them. One of such companies is Preparation for Life/Lawne Green Education (LGE) which has offices in various parts of Lagos, Abuja and Port Harcourt. LGE represents the interest of the Universities of Buckingham, Westminster, West Anglia, Hertfordshire and Glamorgan, among many others.

The advertisements of these universities include attractions such as scholarships, work-study programmes, reputation in marketable courses as well as the employability of their graduates. The courses available include Advance Levels, Foundation courses, degree and postgraduate programmes in more than 150 areas of study (Ojo, 2004).

\section{Networking and Collaboration}

An eager proponent of networking/collaborative effort in the provision of cross-border higher education is John Daniel (Daniel, et al, 1986, 2005). He and his colleagues preach the gospel of collaboration rather than competition in rendering cross-border distance education especially in developing countries (Daniel et al, 2006).

Cooperative networking or twining is a very initiative option that can benefit developing countries. Such networking has recently been initiated between the University of Sussex, England and Adesoye College, Offa in Kwara State, Nigeria. Sussex has given a mandate to Adesoye College to run a one year Foundation Programme for its courses in Engineering, Mathematics, Physics and Information Technology. It is to be expected that this sort of collaborative arrangement would soon be copied by many British and American universities with Nigerian secondary schools that can demonstrate track records of moral integrity, pedagogical competence, academic seriousness, appropriate infrastructures and a conducive learning environment (Ojo, 2004).

Networking has helped in reshaping world outlook and has allowed knowledge to become a monumental pan-human property. Networking within the academics is enhancing a lot of cooperation, harmonization of views, exchanges, linkages, cross-fertilization between scholars belonging to different institutions and research centres within the same country or outside heir countries. Integration also occurs between identical or different linguistic entities, and even between divergent races with distinct and differing cultures, national histories, economic systems and administrative organizations (Ojo, 2004).

From Cotonou, in the neighboring Benin Republic, the Houndegbe North American University is trying to make an in-road into Nigeria. The University claims to be recognized by the government of Benin Republic and to be approved by the Federal Ministry of Education, Nigeria. It offers a two-year (part-time) executive postgraduate Masters programmes in 12 courses such as Marketing, Finance, Business Administration, etc (12 months/1 year), Postgraduate Diploma programmes, five year undergraduate (degree) programmes as 
well as 2-year Diploma courses. These programmes are in various courses in Business Administration, Education Management, law, etc.

Another cooperation/networking in Nigeria is from the Paris Graduate School Management Consultants (PGSM) which is represented in Nigeria by its agent, FNL-Global Educational Management Consultants, located at 30 Ikorodu Road, Lagos. In its advertisement PGSM presented 10 MBA Management courses to be offered through the Distance Learning (DL) mode.

Also from the neighbouring Benin Republic, two specialized government institutions, Village du Benin (in Lome) and the Centre Beninors des Langues Etrangeres (in Cotonou) have been offering cross-border services to their next door neighbours. Although the two institutions do not offer degree programmes or postgraduate degree courses, they have, since their inception in 1968 and 1979 respectively, been involved in providing courses for the French Abroad Immersion (FIP) programmes which 300 level Nigerian undergraduate language students used to go for in France. These two institutions have been actively involved in the teaching of French to Nigerian undergraduates and other categories of Nigerians as well as other Africans, particularly from other Anglophone countries, like Ghana.

Although the FIP is now handled by the Nigerian French village set up in 1991 in Badagry by the Federal Government, the Lome and Cotonou institutions still cooperates with the Nigerian French Village in the areas of teaching, research, publication and short-term intensive programmes in the area of French Studies. There are also five other French language Centres established in various Francophone countries - Senegal Dakar, Coted'Ivoire - Abidjan, Burundi - Bujumbura, Djibouti, and Morocco - Rabat. They all receive active support from France, Canada, USA as well as some international agencies including the Commonwealth Foundation (Ojo, 2004).

Just as the Francophone countries have established French language Centres, there is need for Nigeria, which is surrounded by French-speaking countries, to in like manner set up English Language Centres for the intention of her neighbours. Nigerian universities that are contiguous to our Francophone neighbours should be empowered financially and administratively for this purpose. Towards this end, the University of Lagos could be set up to service Francophone countries on the Southwestern part of the Atlantic Ocean. The University of Maiduguri would service Francophone countries on the northern axis of Nigeria, while the University of Calabar or Port Harcourt will serve Cameroon, which even though it has both English (minority) and majority Frenchspeaking regions, does not cater for the English-speaking residents. A handful of English-speaking Cameroonians were registered for courses with the Distance Learning Institute of the University of Lagos, but the unpredictable time-table, due to unstable political atmosphere, drove them away.

Nigeria can make a major impact on the academic landscape of the West African sub-region through the National Open University of Nigeria (NOUN) which is the region's number one and foremost Distance Learning University that is best financially empowered by any government in the sub-region). NOUN can dispense undergraduate teaching and learning across Nigeria's border through Distance Learning method. NOUN could spread its tentacles through the whole of West Africa. The government of each of the other participating countries of the sub-region would be expected to contribute their own inputs by providing suitable study centres as well as competent local teaching, administrative and supervisory staff. NOUN's origin curriculum could also be revisited to reflect the local needs and specificities and other environmental factors of each participating or recipient country (Ojo, 2004).

There exists international cooperation between some Nigerian universities and foreign institutions. This involves mostly the recently established religious and privately owned universities. These include Covenant, Babcock, Bowen, Benson Idahosa and Madonna Universities which are all Christian religious universities enjoying cooperative linkages with American-based universities. Islamic universities are yet to rise up to the new wave of university creation.

Among the privately owned ones are the Igbinedon University, Okada, Edo State, and ABTI-American University of Nigeria (ABTI-AUN) in Yola. ABTI-AUN is the first private university in the whole of Northern, Nigeria. ABTI-AUN has a special relationship with the University of Washington in the USA. This trend reveals a preponderance of Christian universities learning more towards the South.

The general area of support the American universities tend to offer in the area of provision of Americans as foundation staff, the training of young Nigerian academic staff, curriculum and infrastructural development, academic planning, the setting up of laboratories and libraries.

On the whole, the existence of cross-border providers of higher education should be viewed as a blessing to Nigeria which has hither-to not been able o adequately satisfy its teeming population who thirst for higher education. The cross-border providers should be seen as worthy partners in the raining of the muchneeded high-level manpower for the development and modernization of Nigeria. However, to be appropriately most beneficial, policy guidelines must be established to ensure adequate quality control of providers coming into the country or leaving Nigeria's shores for other countries (Jegede, 2000; Ojo, 2004). Since man is seen as a human capital everything whose objectives are to make life better for human beings should be encouraged. 


\section{Conclusion}

The world has been turned into a global village where borders are diffusing into oblivion. New alliances are being made among formerly adversely opposed nations; the in-thing now is integration and cooperation rather than isolation.

The rapid developments experienced in Information and Communication Technologies has helped in obliterating national and regional boundaries. ICT has grown very rapidly in the last few decades and has drastically increased the volume of information generated and has also changed the means of transferring these information. ICT-induced globalization has made learning a life-long endeavour, and electronic learning (elearning) has the advantage of bringing into the bedrooms of individuals skill-based education and training programmes at reduced costs and at one's convenience.

Knowledge, which is the bedrock of education, has now been seen as a commodity which can be commercialized. This is what WTO/GATS has tried to bring about. But, while ICT-induced globalization and commodification of education is on the high wave in Western countries, the level of connectivity and use of ICT, though it varies from one African country to another, is still very rudimentary in Africa. Rather than integrating, interconnecting, and collaborating in Africa, state-centrism and other myopic factors are bringing Africa backwards, especially with regards to higher education. No African university was named among the best 100 in the world.

Cross-border collaboration would raise Africa's level and standards of higher education. Africa should wake up to the ideals of transcontinental, inter-regional and transnational cooperation and integration so as not to be left askance in the ever-encircling globalization.

\section{References}

[1]. Akinyele, R.T. (2004). Crossborder Provision of Higher Education in Africa: Opportunities, Challenges and Potential Impact. Paper presented at the African University Day Celebration, University of Lagos. 12 Nov., 2004.

[2]. Daniel, J.S. Mugridge, I., Snowden, B.L. and Smith, W.A.S. (1986). Cooperation in Distance Education and Open Learning. http://www.uni-oldenburg.de/zef/cde/policy/DANIEL.DOC.

[3]. Daniel, J.S., Kanwar, A. and Uvalic-Trumbic, S. (2005). Who's afraid of Crossborder Higher Education? A developing World Perspective. Higher Education Digest, Issue 52 Supplement, Cheri, London, pp. 1-8.

[4]. Daniel, J., Kanwar, A., Uvalic-Trumbic, S. and Varoglu, Z. (2006). Collaboration in the Time of Competition. Open and Distance Education in Global Environment (Opportunities for Collaboration), pp. 1-13.

[5]. E.I. (Education International Conference) (2002). $3^{\text {rd }}$. The Impact of Commercialization on Post-Secondary Education: Document prepared for Education International Higher Education and Research Conference. Montreal: March 14-16, 2002.

[6]. Fagbamiye, E.O. (2004). Strategies for Addressing the Challenges of Crossborder Provision of Higher Education, With or Without WTO/GATS Regime. A lead paper delivered at the African University Day Celebration at the University of Lagos on November $12,2004$.

[7]. Jegede, O. (2000). Evolving a National Policy on Distance Education: An Agenda for Implementation. Education Today, Vol.8 (3) 14-29, December, 2000.

[8]. Knight, Jane (2003). Elements and Rules of TATS. Crossborder Education in a Trade Environment, pp. 12-15.

[9]. Knight, Jane (2003). 'Updating the Definition of Internationalization'. International Higher Education. No. 33 Fall 2003 cited in www.bc.educ/bc org/avp/soe/cihe/rewos/atters31/text002.htm.17k.

[10]. OECD, (2000). Education at a Glance, Paris.

[11]. Ojo, S.A. (2004). Identification and Profiling of Cross border Providers, Their Mode of Supply, Programme Focus and Target Recipients within the Context of Nigeria. Being a paper delivered at the African University Day Celebration at the University of Lagos on November 12, 2004

[12]. Marshall, S. (1996). Communicating Change: The role of Communication Studies in Higher Education. http://members.tripod.com/stewartmarshal/ inauguralproflecture.htm.

[13]. Zelezan, P.T. (2003). Rethinking Africa's Globalization. Vol.1. Intellectual Challenges, Africa World Press. New Jersey. 